\title{
The world database for pediatric and congenital heart surgery: A collaboration with the Registro Nacional de Cirugía Cardiaca Pediátrica
}

\author{
La base de datos mundial de cirugía cardíaca pediátrica y congénita: una colaboración \\ con el Registro Nacional de Cirugía Cardíaca Pediátrica (RENACCAPE)
}

\author{
James D. St.-Louis ${ }^{*}$, Jorge Cervantes-Salazar², Alexis Palacios-Macedo ${ }^{3}$, Alejandro Bolio-Cerdán ${ }^{4}$,

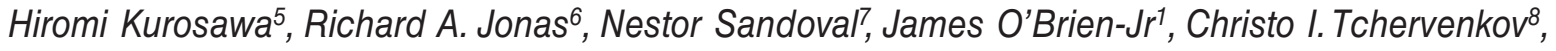 \\ Jeffery P. Jacobs ${ }^{9}$ and James K. Kirklin ${ }^{10}$
}

${ }^{1}$ Department of Surgery, University of Missouri-Kansas City School of Medicine, Kansas City, Missouri, USA; '2Department of Pediatric Cardiac and Congenital Heart Disease Surgery, Instituto Nacional de Cardiología Ignacio Chávez; ${ }^{3}$ Department of Cardiac Surgery, Instituto Nacional de Ciencias Médicas y Nutrición Salvador Zubirán; ${ }^{4}$ Department of Cardiac Surgery, Hospital Infantil de México Federico Gómez. Mexico City, Mexico; ${ }^{5}$ Department of Cardiovascular Surgery, Heart Institute of Japan, Tokyo Women's Medical University, Tokyo, Japan; ${ }^{6}$ Children's National Medical Center, Washington DC, USA; ${ }^{7}$ Department of Cardiovascular Surgery, Instituto de Cardiopatías Congénitas, Fundación Cardioinfantil - IC, Bogotá, Colombia; ${ }^{8}$ Division of Pediatric Cardiovascular Surgery, The Montreal Children's Hospital of the McGill University Health Centre, Montreal, Quebec, Canada; ${ }^{9}$ Department of Surgery, Johns Hopkins All Children's Heart Institute, Johns Hopkins All Children's Hospital and Florida Hospital for Children, Saint Petersburg, Tampa, and Orlando, Florida, USA; ${ }^{10}$ Department of Cardiovascular Surgery, University of Alabama at Birmingham, Birmingham, Alabama, USA

\begin{abstract}
Objective: Following the notable work accomplished by the Mexican Association of Specialists in Congenital Heart Disease (Asociación Mexicana de Especialistas en Cardiopatías Congénitas) with the development of a national registry for congenital cardiac surgery, the World Society for Pediatric and Congenital Heart Surgery has implemented an international platform to collect data and analyze outcomes of children with congenital heart disease. Methodology: This manuscript proposes a possible collaboration between Mexico's national congenital cardiac database (Registro Nacional de Cirugía Cardíaca Pediátrica) and the World Database for Pediatric and Congenital Heart Surgery. Conclusion: Such a partnership would advance the countries' desire for the ongoing development of quality improvement processes and improve the overall treatment of children with congenital heart disease.
\end{abstract}

Key words: Congenital heart disease. Database. Cardiac surgery. Quality improvement. Outcomes. United States of America.

\section{Resumen}

Objetivo: Siguiendo el notable trabajo realizado por la Asociación Mexicana de Especialistas en Cardiopatías Congénitas (Asociación Mexicana de Especialistas en Cardiopatías Congénitas: AMECC) con el desarrollo de un registro nacional para la cirugía cardíaca congénita, la Sociedad Mundial de Pediatría y Cirugía Cardíaca Congénita ha implementado una

Correspondence:

*James D. St. Louis

E-mail: jdstlouis@cmh.edu
Date of reception: 17-08-2017

Date of acceptance: 19-06-2018

DOI: 10.24875/ACM.M19000027
Available online: 0x-0x-2019 Arch Cardiol Mex. 2019;89(2):112-116 www.archivoscardiologia.com 1405-9940 @ 2018 Instituto Nacional de Cardiología Ignacio Chávez. Published by Permanyer México. This is an open access article under the CC BY-NC-ND license (http://creativecommons.org/licenses/by-nc-nd/4.0/). 
plataforma internacional para recopilar datos y analizar los resultados de los niños con cardiopatía congénita. Metodología: Este manuscrito propone una posible colaboración entre la base nacional de datos cardiacos congénitos de México (RENACCAPE) y la Base de Datos Mundial para la Cirugía Cardíaca Pediátrica y Congénita (WDPCHS). Conclusión: Esta asociación promovería el deseo de los países de seguir desarrollando procesos de mejora de la calidad y mejorar el tratamiento general de los niños con cardiopatía congénita.

Palabras clave: Cardiopatía congénita. Base de datos. Cirugía cardíaca. Mejora de calidad. Resultados. Estados Unidos de América.

In 2007, the historic inaugural meeting of the World Society for Pediatric and Congenital Heart Surgery (WSPCHS) was convened in Washington D.C. The organizers and participants of this event were motivated and inspired by the prospect of a new era of global communication in the field of congenital heart disease. Their mission, galvanized with ratification of the society's constitution, directed members to promulgate efforts to "to promote the highest quality of comprehensive cardiac care to all patients with congenital heart disease, from the fetus to the adult, regardless of the patient's economic means, with an emphasis on excellence in education, research, and community"1,2. Shortly following this meeting, the Mexican Association of Specialists in Congenital Heart Disease (Asociación Mexicana de Especialistas en Cardiopatías Congénitas [AMECC]) was created to partner with the WSPCHS for the purpose of fulfilling this mission in Mexico. This group of prestigious pediatric cardiologists and cardiac surgeons, with governmental support, began to work on several initiatives, including the initiation of a national registry, a plan for regionalization of congenital cardiac care, and an evaluation of current resources dedicated to the treatment of congenital heart disease within the country. The Pediatric Cardiovascular Surgical Database Registry/Registro Nacional de Cirugia Cardiaca Pediatrica (RENACCAPE), which would collect information about the practice of congenital heart surgery within the country, was launched as a national effort ${ }^{3}$. In 2012, RENACCAPE was able to recruit 11 congenital cardiac surgical programs, with annual case volumes ranging from 70 to $690^{4}$. Table 1 provides a representation of the case complexity over a 1-year period for centers submitting to this national registry (Table 1). However, due to both financial limitations and the hesitation of many centers to publically report their surgical outcomes, participation in the database slowed, resulting in the temporary suspension of its activity.

Nevertheless, following the initial excellent work achieved by AMECC, the WSPCHS has worked to implement a process by which information concerning the practice of congenital cardiac surgery will be
Table 1. Surgical procedures performed from August 1, 2011, to July $31,2012^{a}$

\begin{tabular}{|l|c|}
\hline Surgical procedures & Cases (\%) \\
\hline Septal defect repair & $109(12)$ \\
\hline Closure of patent ductus arteriosus & $97(10)$ \\
\hline Repair of systemic to pulmonary fistula & $85(9)$ \\
\hline Correction of TAPVC & $67(7)$ \\
\hline Repair of atrial septal defect & $64(7)$ \\
\hline Aortic coarctation repair & $55(6)$ \\
\hline Tetralogy of Fallot repair & $57(6)$ \\
\hline Atrioventricular canal correction & $33(3)$ \\
\hline Pulmonary artery cerclage & $23(2)$ \\
\hline Bidirectional cavopulmonary derivation & $28(3)$ \\
\hline Total cavopulmonary connection (fontan) & $21(2)$ \\
\hline Mitral valve surgery & $21(2)$ \\
\hline Jatene surgery & $14(1)$ \\
\hline Jatene surgery + VSD closure & $13(1)$ \\
\hline Subvalvular aortic stenosis repair & $11(1)$ \\
\hline Arterial trunk total correction & $11(1)$ \\
\hline Correction of PAPVC & $11(1)$ \\
\hline Double outlet right ventricle repair & $10(1)$ \\
\hline Aortic arch repair & $7(1)$ \\
\hline Other procedures & $206(22)$ \\
\hline Ada & \\
\hline
\end{tabular}

${ }^{a}$ Adapted from Cervantes-Salazar J, Calderon-Colmenero J, Ramirez-Marroquin S, et al. Pediatric cardiovascular surgical database registry in Mexico: First report. Rev Invest Clin. 2013. PAPVC: partial anomalous pulmonary venous connection; TAPVC: total anomalous pulmonary venous connection; VSD: ventricular septal defect

recorded and analyzed on a global scale ${ }^{5}$. During the $4^{\text {th }}$ Scientific Meeting of the WSPCHS held in Sao Paulo, Brazil, a Town Hall meeting entitled "A World Database for Pediatric and Congenital Heart Surgery (WDPCHS)" was convened to explore the possibility of establishing a global database that would be available to all members of the World Society. After much 
Table 2. Data collection forms

\begin{tabular}{|l|l|}
\hline Form name & Data to be entered \\
\hline Institutional practice details & $\begin{array}{l}\text { Information detailing institution's congenital cardiac surgical practice (e.g., annual case volume, } \\
\text { population and region served, number of congenital heart surgeons) }\end{array}$ \\
\hline Demographics & $\begin{array}{l}\text { Patient information (e.g., patient name, gender, DOB) } \\
\text { Pre-operative details of patient history (e.g., prior cardiac operations, chromosomal or syndromic } \\
\text { abnormalities, and pre-operative risk factors) }\end{array}$ \\
\hline Surgery & \begin{tabular}{l} 
Surgical data (e.g., height and weight at surgery, bypass time, and cross-clamp time) \\
\hline Discharge
\end{tabular} \\
\hline $\begin{array}{l}\text { Complication and discharge information (e.g., reoperations required, nature of post-operative } \\
\text { complications) }\end{array}$ \\
\hline Follow-up & $\begin{array}{l}\text { Data from 1-year post-index operation (e.g., readmission required, reoperation required, and patient } \\
\text { status) }\end{array}$ \\
\hline Death & Details of death (e.g., date of death, cause of death, and autopsy findings) \\
\hline
\end{tabular}

debate and consideration, the Database Committee received the mandate to establish a database which would collect vital information, allowing all centers to benchmark their outcomes and progress in providing surgical care to children with congenital heart disease. The effort to establish a global database continued at the Joint Scientific Meeting of the World Society with Sociedad Latina de Cardiologia y Cirugia Cardiovascular Pediatrica held in Cartagena, Colombia, in February of 2015.

The WSPCHS was fortunate to retain the services of the James and John Kirklin Institute for Research in Surgical Outcomes (KIRSO) at the University of Alabama at Birmingham. Under the leadership of James K. Kirklin, KIRSO has been responsible for the creation and current maintenance of both nationally and internationally acclaimed clinical databases. With the experience of this institute and invaluable input from multiple international experts in the fields of both congenital heart disease and database development, a global platform for information exchange was created and adjudicated by members of the society. The WDPCHS went live on January 1, 2017, following an extensive period of planning focused on determining the appropriate variables to collect, creating a design that can be applied on a global scale regardless of socioeconomic status, and engaging in strategies to encourage international participation.

The WDPCHS is designed to produce meaningful performance and quality analyses of surgical outcomes that extend beyond immediate hospital survival, capturing important morbidities and mortalities for up to 1 year postoperatively. By utilizing standardized terms and definitions developed and adjudicated by several national and international expert organizations $s^{6,7}$, the World Database has embraced a common language, communication, and assessment of congenital cardiac practices across the globe. To provide individual centers adequately detailed outcomes analyses while remaining cognizant of limited financial and personnel resources, variables were selected to provide the greatest opportunity to evaluate programmatic deficiencies and to effect necessary improvements in pre-operative selection, intraoperative performance, and post-operative management. Institutions will be able to confidentially compare their center-specific data to regional, national, and international aggregate data, allowing for the identification and implementation of quality improvement strategies.

Table 2 illustrates the organization of the World Database and the types of information that are being collected (Table 2). Institutional practice data are collected in sufficient detail to facilitate the creation of an international registry of congenital cardiac centers. Such information collected includes annual center case volumes, the number of congenital cardiac surgeons actively practicing in the center, geographic region served, population served, the number of other institutions within the geographic region, and a description of the services provided. The surgery form requires the input of only 17 variables. Several of these variables, such as primary cardiac procedure and cardiac diagnosis, are organized into easy-to-navigate drop-down menus categorized for routine clinical practice. These variables, including prior 
cardiac operations, pre-operative risk factors, weight, cardiopulmonary bypass times, and intraoperative complications, were chosen by international experts in the field of congenital cardiac surgery to reliably represent the operative components of a surgical program. The collection of follow-up information on readmission, morbidities, and mortalities for up to 1 year after surgery is a distinguishing feature that separates this database from others. This longitudinal follow-up will for the $1^{\text {st }}$ time provide a global picture of longitudinal care beyond the immediate post-operative period.

Data quality is critical, and collection of too much data may lead to the dilution of efficient and effective analysis, increased expenditure of valuable resources, and loss of enthusiasm from participating members. For these reasons, surgical procedures are assigned to one of two categories within the database. This twotiered system was created to allow for both the input of detailed data for a pre-selected group of surgical procedures and collection of a limited number of variables for all cardiac operations performed (Table 3). Additional follow-up data cover important morbidities, readmission for intervention related to the index surgical procedure, and mortality for up to 1 year postoperatively. Importantly, the database will maintain the flexibility to incorporate additional procedures in the Tier I category as centers gain experience with the database and understand its value, both for quality assurance and research.

To advance its mission, the WSPCHS has made this global quality improvement program available to its individual members free of charge. On a national level, congenital cardiac programs in Mexico that lack sufficient resources and facilities to undertake sophisticated outcomes analyses will be able to utilize this service with limited dedication of resources. Centers are assured that their data are only identified to their institution. Centers will also have the ability to draw comparisons to deidentified regional and national aggregate outcomes. With this in mind, there exist two possible avenues by which the WDPCHS could be implemented within Mexico. First, recent efforts by many leaders in congenital cardiac surgery and pediatric cardiology have reengaged the RENACCAPPE registry and will begin recruiting patients in the very near future. If this successful, it would be possible to establish a cross-map with WDPCHS, allowing centers to submit their RENACCAPE data to WDPCHS with little additional expenditure of valuable resources. The center-specific data could then be benchmarked against international aggregate data, allowing for the
Table 3. Tier I procedures

\section{Procedure name}

VSD repair

Atrioventricular septal defect repair

Coarctation repair

PAPVC repair

TAPVC repair

Glenn/hemi-Fontan procedure

Fontan procedure

Tetralogy of Fallot repair

Arterial switch operation

Ebstein's anomaly repair

Truncus arteriosus repair

Modified Norwood procedure

HLHS biventricular repair

VSD: ventricular septal defect; HLHS: hypoplastic left heart syndrome; PAPVC: partial anomalous pulmonary venous connection; TAPVC: total anomalous pulmonary venous connection

development of quality improvement projects and processes to improve overall outcomes. Alternatively, if this national database lacks the resources and supports necessary to maintain such a costly endeavor, and then, the WDPCHS could be modified to serve as a primary national resource for the collection and evaluation of information that would contribute to the improvement of overall care of children with congenital heart disease within Mexico. In any case, finally, being able to create a national database within Mexico is of utmost importance to AMECC and the WSPCHS. It is the responsibility of both of these organizations to make the government aware of the need for a reliable source of information to improve the quality of care for congenital heart disease throughout Mexico and to assist in defining its health-care policies for decades to come.

With the creation of the WDPCHS, the WSPCHS is taking an essential step in the process of global improvement of care for children with pediatric and congenital heart disease. Regardless of the specific path chosen by the governing organizations within Mexico, the World Society invites all its members and partners to fully participate in this important initiative. More detailed information concerning the WDPCHS can be found at http://www.uab.edu/medicine/wdpchs/. 


\section{Conflicts of interest disclosure}

The authors have no conflicts of interest to disclose.

\section{Funding}

The authors have no funding to disclose for this project.

\section{Ethical disclosures}

Protection of human and animal subjects. The authors declare that no experiments were performed on humans or animals for this study.

Confidentiality of data. The authors declare that no patient data appear in this article.

Right to privacy and informed consent. The authors declare that no patient data appear in this article.

\section{References}

1. Tchervenkov $\mathrm{Cl}$, Stellin $\mathrm{G}$, Kurosawa $\mathrm{H}$, et al. The world society for pediatric and congenital heart surgery: its mission and history. Semin Thorac Cardiovasc Surg Pediatr Card Surg Annu. 2009;1:3-7.

2. Tchervenkov $\mathrm{Cl}$, Jacobs JP, Bernier PL, et al. The improvement of care for paediatric and congenital cardiac disease across the world: a challenge for the world society for pediatric and congenital heart surgery. Cardiol Young. 2008;18 Suppl 2:63-9.

3. Cervantes-Salazar J, Calderon-Colmenero J, Ramirez-Marroquin S, et al Pediatric cardiovascular surgical database registry in Mexico: first report. Rev Invest Clin. 2013;65:476-82.

4. Calderón-Colmenero J, Cervantes-Salazar J, Curi-Curi P, Ramírez-Marroquín S. Congenital heart disease in Mexico: advances of the regionalization project. World J Pediatr Congenit Heart Surg. 2013; 4:165-71.

5. Kirklin JK, St Louis JD. Databases in pediatric cardiac surgery: a nexus of opportunity and obligation. World J Pediatr Congenit Heart Surg. 2016; 7:675-6.

6. Béland MJ, Franklin RC, Jacobs JP, et al. Update from the international working group for mapping and coding of nomenclatures for paediatric and congenital heart disease. Cardiol Young. 2004;14:225-9.

7. Franklin RC, Jacobs JP, Tchervenkov Cl, Béland MJ. Bidirectional crossmap of the short lists of the European paediatric cardiac code and the international congenital heart surgery nomenclature and database project. Cardiol Young. 2002;12:431-5. 